\title{
Growth and mortality patterns evaluated from otolith microstructure in Atlantic cod Gadus morhua larvae reared on different feeding regimes in mesocosms
}

\author{
Terje van der Meeren ${ }^{1, *}$, Erlend Moksness ${ }^{2}$ \\ ${ }^{1}$ Institute of Marine Research, Austevoll Aquaculture Research Station, 5392 Storebø, Norway \\ ${ }^{2}$ Institute of Marine Research, Flødevigen Marine Research Station, 4817 His, Norway
}

\begin{abstract}
The objective of this work was to test the hypothesis that in a situation where predators are excluded growth and mortality rates of cod larvae should be independent. This was evaluated from distributions of otolith increments in larvae sampled at different times of development. The mesocosm experiment was carried out in four $5.2 \mathrm{~m}^{3}$ plastic-bag enclosures placed along a raft system in a $20000 \mathrm{~m}^{3}$ seawater pond used for zooplankton production. Two different feed regimes (low and high ration, each in 2 enclosures) were set up on the basis of a fixed specific growth rate (SGR) applied in a bioenergetic model. Cod larvae showed a very dynamic relationship to food availability and larval growth. An increase in prey size after Day 20 had profound effects on otolith growth, which responded rapidly to availability of suitable prey. Thus, a short-term change in feeding conditions seems to be easily tracked in otoliths of cod larvae. The overall relationship between otolith radius and larval length was not linear, indicating a certain degree of decoupling between otolith and somatic growth. In a situation with adequate feeding conditions and exclusion of predators, mortality was not clearly dependent on otolith growth or size. This indicates that no strong inherent mechanisms in the larvae are responsible for growth- or size-dependent mortality.
\end{abstract}

KEY WORDS: Cod larvae · Otolith dynamics · Selective mortality · Feeding regimes · Growth history · Larval rearing $\cdot$ Mesocosms

Resale or republication not permitted without written consent of the publisher

\section{INTRODUCTION}

Mortality in fish larvae at sea may vary considerably during larval development. The early stages seem to face much higher levels of mortality than older larvae (Peterson \& Wroblewski 1984, McGurk 1986, Cowan \& Houde 1992, Houde 1997). Similar observations have also been reported for Atlantic cod Gadus morhua L. (Sundby et al. 1989, Kristiansen et al. 1997). Further, mortality during larval development seems to be linked to growth and associated with size-specific mechanisms (Ware 1975, Pepin 1989). Predation is probably the most important component of larval mortality in marine fishes (Bailey \& Houde 1989). However, the total effect of predation on cumulative mortality is dependent on larval growth rate (Houde 1989). Natural mortality de- clines with increasing body size, and rapid growth provides a refuge from mortality (Kiørboe 1989). Hence, size-specific mortality will mirror growth-dependent mortality: slow-growing individuals in a population will end up as small individuals in a population, and will risk a higher probability of predation mortality. If predation is size-selective and responsible for diminishing larval survival by several orders of magnitude, evolution of a high larval growth potential is expected. Such high growth capabilities have been found in experimental studies with a number of larval fish species (Houde \& Schekter 1981, Øiestad 1985, Houde 1989, Margulies 1989, Paulsen \& Andersen 1989, Cowan \& Houde 1990, van der Meeren \& Næss 1993), demonstrating that genetic restrictions to enter 'the refuge of growth' probably do not exist. 
Studies that confirm size-specific (and hence growth-dependent) mortality in the natural environment of fish larvae are scarce, but the effect has been shown (Post \& Prankevicius 1987, Tsukamoto et al. 1989, Grimes \& Isely 1996). A similar relationship between growth rate and survival occurred in a patch tracking study on herring Clupea harengus L. larvae (Gallego \& Heath 1997). If predation is the main component of these selective forces, size- or growthdependent mortality should not be a major characteristic of larval survival in systems where predators are absent, unless such mechanisms are also linked to other factors. In that respect, selective mortality has been reported in predator-free mesocosm experiments and linked to adverse feeding conditions or starvation (Rosenberg \& Haugen 1982, Folkvord et al. 1997). Selective mortality was also demonstrated in the sea for cod larvae, around the expected time for starved larvae to die during the early first-feeding period (Grønkjær \& Schytte 1999). In experimental work with fish larvae, size-selective mortality may be initiated by food limitation and bias estimation of larval growth rates (Blom et al. 1994).

In relation to the work undertaken so far, the objective of this study was to simulate a field patch-tracking study on cod larvae in a controlled mesocosm system where food levels and predators can be manipulated. Daily larval growth was investigated from otolith microstructure. One hypothesis to be examined was that in a situation where predators are excluded, mortality should not be selective on larval growth or size. To evaluate the effect of feeding conditions on growth and survival, the experiment was carried out under 2 different feeding regimes: high and low food availability.

\section{MATERIALS AND METHODS}

The mesocosm experiment was carried out at the Institute of Marine Research, Austevoll Aquaculture Research Station. Four plastic bag enclosures, each measuring $5.2 \mathrm{~m}^{3}$, were placed along a raft system in a $20000 \mathrm{~m}^{3}$ seawater pond used for production of zooplankton (Naas et al. 1991, van der Meeren et al. 1994). The bags were filled with $80 \mu \mathrm{m}$ filtered surface seawater from the open fjord outside the pond. Approximately 2400 cod larvae, hatched from 1 hand-stripped egg batch of 1 female, were stocked $3 \mathrm{~d}$ post-hatch in each of the plastic bag enclosures. To check the possible effects of handling and transport, a control group of 100 larvae was placed in each of four 31 transparent plastic bags. To ensure temperature control, these bags were kept floating in the drain water from the filter that renewed the water in the rearing units. The water in the rearing enclosures was renewed at a daily rate of 10 to $15 \%$, but changed to $40 \%$ at Day 29 posthatch to maintain oxygen levels. Hydrographical data (temperature, salinity and oxygen saturation) were collected at 1 to $4 \mathrm{~d}$ intervals.

Feeding conditions. Live copepod nauplii and copepodites were collected from the pond by an UNIK-900 wheel filter and used as food for the cod larvae (van der Meeren \& Naas 1997). In this filter, plankton are concentrated and size-graded between rotating plankton net wheels. The mesh sizes on the nets decide which plankton fraction to collect. Initially, the bags were stocked with copepod nauplii (mostly Eurytemora affinis) collected in the range of 80 to $250 \mu \mathrm{m}$. Subsequent changes of upper mesh size to 150, 180, and $250 \mu \mathrm{m}$ were done on Days 4, 9, and 15 post-hatch, respectively. From Day 23, the size fraction $>250 \mu \mathrm{m}$ was also included.

Feeding was carried out according to calculated food demands from a theoretical bioenergetic model for small fish larvae (van der Meeren 1991). As mortality could not be monitored throughout the experiment, larval feeding requirements were calculated as if all larvae should survive. Two bags (Bags 1 and 2) received a 'high-ration' prey level, corresponding to a calculated daily specific growth rate (SGR) of $12.5 \%$, while the last 2 bags (Bags 3 and 4) received a 'lowration' food level, equivalent to a SGR of $7.5 \%$.

Sampling and measurements of larval growth. On Days 10 and 20, between 35 and 40 larvae were collected from a sample (with a $250 \mu \mathrm{m}$ net) for lengthweight measurements and readings of otolith ring structure. On Day 31 post-hatch, the experiment was terminated. The bags were emptied through a $250 \mu \mathrm{m}$ plankton net with a $2.5 \mathrm{l}$ watertight tube as a cod-end. Surviving larvae were counted, and a subsample of 40 larvae was collected for length, myotome height, weight, and otolith measurements. Percent survival was calculated as final counts divided by the difference between initial numbers and total numbers sampled on Days 10 and 20. To prevent shrinking, standard length and myotome height were measured on fresh larvae placed in a water-cooled glass petridisc. After the morphometric measurements the larvae were frozen at $-28^{\circ} \mathrm{C}$ before drying in a Heto FD8 freeze-drier. Dry weight was determined with a Mettler 3M microbalance $( \pm 0.0001$ $\mathrm{mg}$ ) after the larvae were kept $24 \mathrm{~h}$ on silica gel in an exicator. Somatic growth was determined from a modified Laird-Gompertz equation (Øiestad 1983, van der Meeren \& Næss 1993) fitted to the data (Eq. 1). Growth was evaluated as SGR, which is \% daily increase in weight $\left(\mathrm{SGR}_{\mathrm{DW}}\right)$ or standard length $\left(\mathrm{SGR}_{\mathrm{SL}}\right)$. These measures were calculated from an exponential model (Ricker 1958) (Eq. 2), both between 
the actual samples and for each day, based on lengths or weights calculated from Eq. (1):

$$
\begin{gathered}
W_{t_{n}}=A \mathrm{e}^{B \mathrm{e}^{C\left(1-\mathrm{e}^{D\left(t_{n}-t_{0}\right)}\right)}} \\
\mathrm{SGR}=\left(\mathrm{e}^{g}-1\right) \times 100 \% \quad \text { where } g=\frac{\ln \left(W_{t_{2}}\right)-\ln \left(W_{t_{1}}\right)}{t_{2}-t_{1}}
\end{gathered}
$$

In Eqs. (1) \& (2), $W$ is dry weight or standard length, $A$ to $D$ are constants found by iteration, $t_{1}$ and $t_{2}$ represent larval age of subsequent samples, $t_{0}$ is age at stocking of the enclosures (first sample), and $t_{\mathrm{n}}$ is age (days post-hatch). The expression $A \mathrm{e}^{B}$ in Eq. (1) corresponds to larval dry weight or standard length at stocking $\left(W t_{0}\right)$.

Otolith processing and measurements. The otoliths were processed and analysed at the Institute of Marine Research, Flødevigen Marine Research Station. As noted by Suthers (1996), the lapillus was chosen because (1) it is the largest otolith for the first 5 to $15 \mathrm{~d}$, and consequently has the most complete resolvable growth, (2) it has an eccentrically located nucleus and grows linearly from the nucleus without secondary primordia until at least 150 increments, and (3) growth in the sagitta becomes so rapid compared to the lapillus that sub-daily rings may be hard to distinguish. The dried cod larvae were placed in $96 \%$ ethanol. Both lapillus otoliths were dissected out under a dissecting microscope with crossed polarised light and mounted on glass slides with clear nail polish. Whenever it was required to increase the readability of the Day 31 sample, the otoliths were polished with fine grit paper (3M lapping film, 30 and $1 \mu \mathrm{m}$ grit). Hatch check (focus) was determined, and radius was always measured as the longest distance from the hatch check to the otolith margin. Daily increments were counted and measured, preferably along the radius with an image analyser computer system (OTO: Butler \& Moksness 1997) at 1000× magnification. Otolith characteristics and growth were evaluated as averages of the 2 lapilli of daily increment width, radius, and daily relative otolith growth rate (RGR in Eq. 3; Suthers et al. 1999):

$$
\mathrm{RGR}=\frac{\text { width of increment }_{n}}{\operatorname{radius}_{(n-1)}} \times 100 \%
$$

To evaluate growth-dependent mortality, distributions of increment width, RGR and radius at the same increment (age) were compared for different samples within each bag enclosure. Consequently, width, RGR and radius of Increment 10 were compared for Day 10, 20 and 31 samples. Similarly, Increment 20 was compared between Day 20 and 31 samples. Before comparison, distributions were tested by KolmogorovSmirnov tests for normality (goodness of fit, Lilliefors $p$-values). Several of the distributions did not fit the normal distribution, and a Kolmogorov-Smirnov 2-sample test was therefore used to compare the distributions of otolith characteristics. The KolmogorovSmirnov 2-sample test was chosen because it tests differences in both location and shape (dispersion, skewness, etc.) of the trait distributions (Sokal \& Rohlf 1995). Significant differences in increment width, RGR and radius of the surviving population within 1 bag enclosure relative to earlier samples were interpreted as growth- or size-dependent mortality. Increments 10 and 20 of the Day 31 sample were also tested between bags within each feeding regime. Both within and between bags, a sequential Bonferroni correction for multiple comparisons (the Dunn-Šidák method) were used to adjust significance level for reducing Type I error (Sokal \& Rohlf 1995).

To evaluate whether a larva was able to maintain its position with respect to growth or size in the population hierarchy, Spearman's rank correlation coefficient $\left(r_{s}\right)$ was calculated between ranked otolith characteristics (increment width, RGR and radius) of the last and previous increments. Differences in standard length, myotome height, dry weight and survival were tested by ANOVA with replicate bags nested under each feeding regime. Survival percentages were arcsinetransformed before analysis (Sokal \& Rohlf, 1995). Correlations between otolith radius and larval size were compared by ANCOVA, with replicate bags nested under each of the 2 feeding regimes. Significance level in all statistical tests was set to $\mathrm{p}=0.05$.

\section{RESULTS}

\section{Environment, feeding conditions, survival and somatic growth}

Temperature was initially $8.8^{\circ} \mathrm{C}$ in the bags, and increased to a maximum of $11.9^{\circ} \mathrm{C}$ on Day 26 posthatch. Salinity decreased slowly from 32.3 to $31.2 \%$. Oxygen saturation varied between 98 and $119 \%$. No stratification in any of the hydrographical parameters was observed in the bags.

Survival in the plastic-bag enclosures was on average $48.1 \% \pm 5.2$ (SD). No difference was found between high- and low-ration treatments (ANOVA, df $=3, p=0.644$,). Survival in the control group was 100, 97, 80 and $40 \%$ on Days 1, 4, 8 and 12 after stocking, respectively, indicating that any mortality due to handling can be excluded. At the end of the experiment, the larvae from the 2 bags receiving the low food ration were 2.15 and $2.54 \mathrm{mg}$, while in the high-ration feeding regime the larvae were 4.18 and $3.95 \mathrm{mg}$. In the first 3 wk, growth (average $\mathrm{SGR}_{\mathrm{DW}}$ between the samples) at the population level was high (starting at 
14.0 to $17.1 \%$ before Day 10 , increasing to 20.5 to $23.6 \%$ between Days 10 and 20) and independent of feeding regime (Fig. 1). In the 4 th week, $S_{G R}$ became more in accordance with the expected SGR from the bioenergetic food consumption model. $\mathrm{SGR}_{\mathrm{DW}}$ curves generated from weights calculated by the modified Laird-Gompertz equations showed similar results (Fig. 1).

Larval length reached 12.1 and $12.7 \mathrm{~mm}$ in the lowration bags, while in the high-ration bags larval length was 14.4 and $14.6 \mathrm{~mm}$ (Fig. 1). Average daily length growth was similar for all bags up to Day 20 (0.16 to $0.19 \mathrm{~mm} \mathrm{~d}^{-1}$ between Day 3 and 10, and 0.37 to $0.40 \mathrm{~mm} \mathrm{~d}^{-1}$ between Day 10 and 20). In the last period of the experiment, the 2 feeding regimes separated, showing $0.44 \mathrm{~mm} \mathrm{~d}^{-1}$ for both bags in the high-ration group, and 0.26 to $0.29 \mathrm{~mm} \mathrm{~d}^{-1}$ in the low-ration group. Specific growth in length $\left(\mathrm{SGR}_{\mathrm{SL}}\right)$ increased in all bags to a maximum of 5.7 to $5.9 \%$ around Day 15 (Fig. 1), and decreased in a similar manner as for $\mathrm{SGR}_{\mathrm{DW}}$ in the 4th week. On Day 31, larval myotome height reached $1.95 \mathrm{~mm}$ in the high-ration bags (SD: 0.24 and $0.16 \mathrm{~mm}$ ), and 1.48 and $1.54 \mathrm{~mm}$ in the low-ration bags (SD: 0.24 and 0.23 , respectively).

Differences between the feeding regimes in larval length, myotome height or weight occurred only in the
Day 31 sample (ANOVA, $\mathrm{df}=135$ or 136, p-values $<1.3$ $\times 10^{-21}$ ). No differences in these parameters occurred between the 2 bags of each feeding regime at any sampling time (ANOVA, $\mathrm{df}=135$ or 136 , p-values $>0.07$ ).

For most of the experimental period, food was administered according to the food consumption model (Fig. 2). The number of plankton added daily increased prey concentration, on average, by 146 and 92 copepods $1^{-1}$ in the high- and low-ration bags, respectively. Copepodites contributed significantly in biomass to the prey composition from Day 12 and onwards. On 3 of the $4 \mathrm{~d}$ from Day 22 to 25 , food supply was below that calculated by the consumption model. In this period, food composition also switched to larger prey, and adult copepods became the most abundant food organism.

\section{Otolith characteristics}

Otolith size and number of increments for the different samples are given in Table 1. Except for the Day 3 and 20 samples, 1 to 4 increments less than expected for larval age were found. In the Day 3 sample, $10 \%$ of the larvae had either 1 ring less or more than expected for age. Although the larvae originated from one single egg batch, this indicates that hatching occurred over
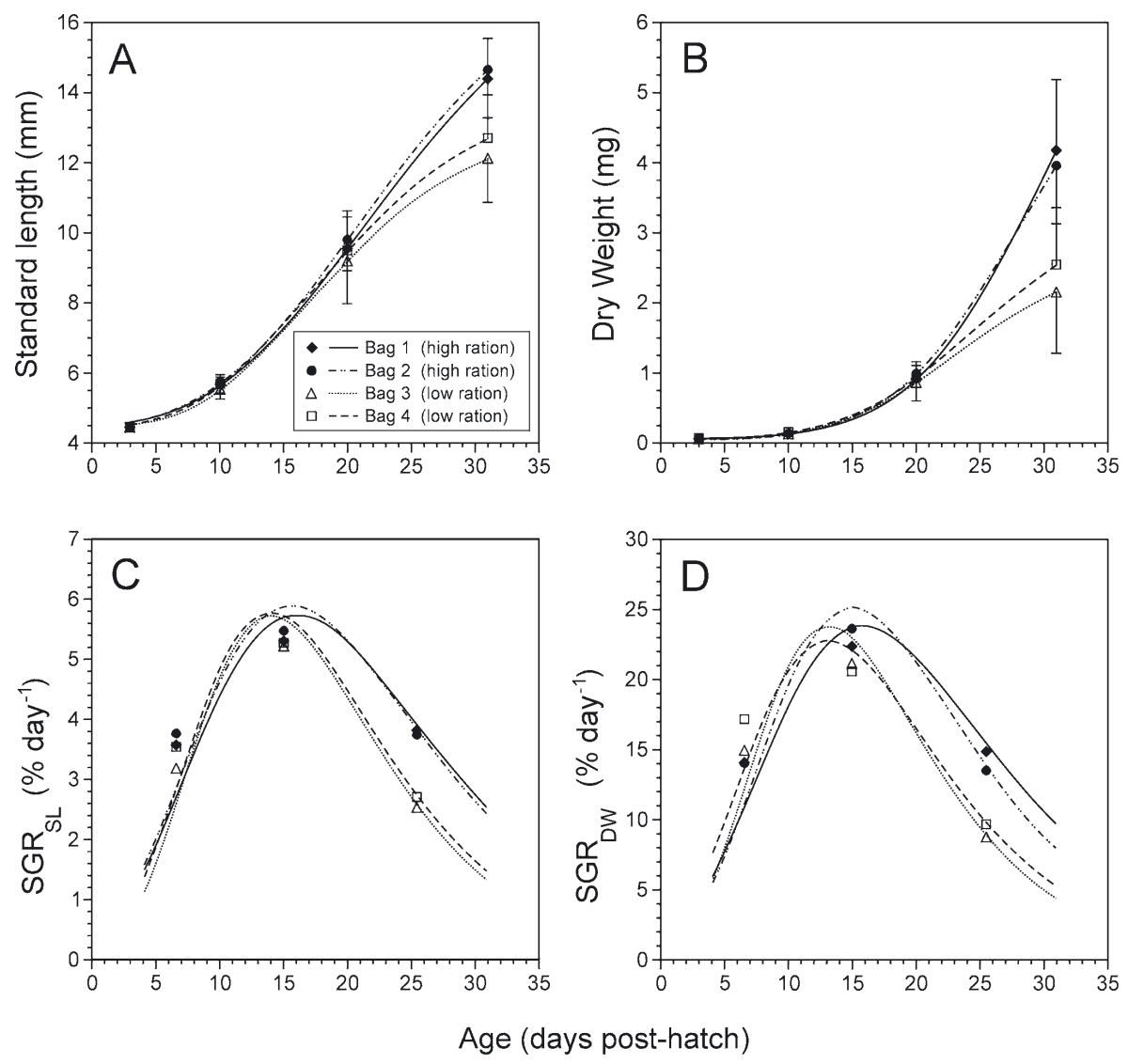

Fig. 1. Gadus morhua. Larval population growth of cod in the bag enclosures. (A) Standard length, (B) dry weight, (C) length-specific growth rate $\left(\mathrm{SGR}_{\mathrm{SL}}\right)$, (D) weightspecific growth $\left(\mathrm{SGR}_{\mathrm{DW}}\right)$. Curves are calculated from the modified Laird-Gompertz equations (Eq. 1), while the symbols represent actual observations $(\mathrm{A}, \mathrm{B})$ or values for exponential growth between the samples $(C, D)$. Mean values $\pm S D$ are shown 

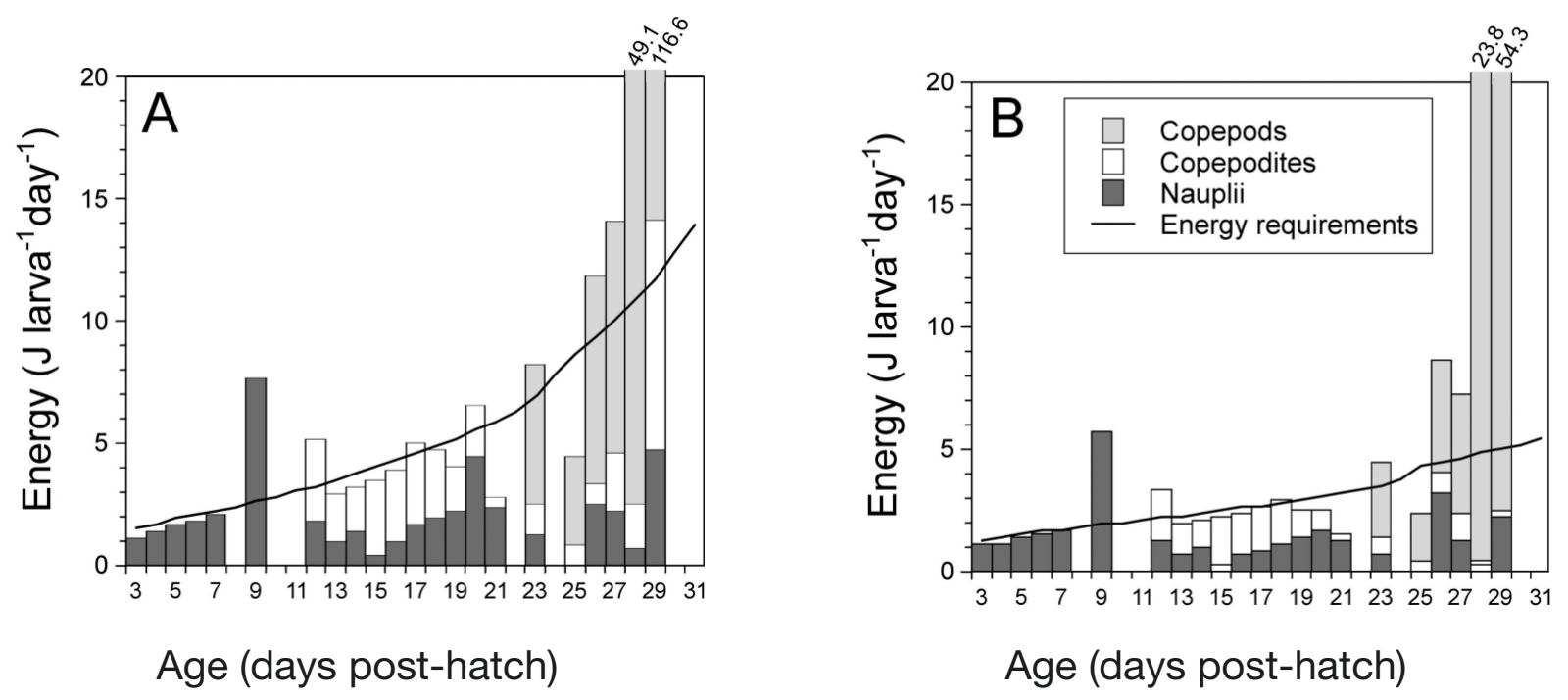

Fig. 2. Gadus morhua. Feeding regimes in relation to prey availability and larval requirements. Feeding conditions for (A) highration and (B) low-ration groups, given as estimated energy in plankton added daily per larva (bars), compared to larval requirement calculated from food consumption (solid line). Calculations are corrected for mortality, assumed to be exponential according to initial and final larval numbers

$3 \mathrm{~d}$, and that $80 \%$ of the larvae hatched on the day of bulk hatching. In older larvae, small increments were hard to read, particularly close to the hatch check. Therefore, age (day number) was assigned to the increments of an otolith in reverse order, i.e. the last increment equalled the age at sampling.

Figs. 3 \& 4 show increment width, RGR, and radius in relation to larval age (increment number) for the highand low-ration feeding regimes, respectively. Increment width increased in all bags for all samples up to Day 26. In the high-ration bags, both increment width and RGR of the Day 20 sample tended to be lower than

Table 1. Gadus morhua. Number of increments, radius, and radius of hatch check (focus), given as mean of the 2 lapillus otoliths. SGR: specific growth rate

\begin{tabular}{|ccccccccccc|}
\hline \multirow{2}{*}{$\begin{array}{c}\text { Age } \\
(\mathrm{d})\end{array}$} & $\begin{array}{c}\text { Food regime } \\
(\% \text { SGR })\end{array}$ & Bag & \multicolumn{2}{c}{ No. of } & \multicolumn{2}{c}{ No. of increments } & \multicolumn{2}{c|}{ Radius $(\mu \mathrm{m})$} & \multicolumn{3}{c|}{ Focus $(\mu \mathrm{m})$} \\
\hline 3 & - & $1-4$ & 19 & 3.00 & 0.47 & 12.65 & 0.61 & 9.54 & 0.76 \\
& & & & & & & & & & \\
10 & 12.5 & 1 & 29 & 6.90 & 1.26 & 19.55 & 1.37 & 11.45 & 1.58 \\
10 & 12.5 & 2 & 33 & 9.09 & 1.21 & 19.14 & 0.95 & 10.00 & 0.66 \\
10 & 7.5 & 3 & 36 & 8.31 & 2.04 & 18.66 & 1.65 & 10.35 & 1.04 \\
10 & 7.5 & 4 & 38 & 7.68 & 1.09 & 19.73 & 1.05 & 10.66 & 0.86 \\
& & & & & & & & & & \\
20 & 12.5 & 1 & 31 & 20.00 & 1.48 & 36.51 & 3.46 & 10.09 & 0.73 \\
20 & 12.5 & 2 & 34 & 19.74 & 1.76 & 37.58 & 3.73 & 10.11 & 0.95 \\
20 & 7.5 & 3 & 28 & 19.25 & 2.63 & 36.39 & 3.77 & 10.50 & 1.10 \\
20 & 7.5 & 4 & 34 & 20.56 & 2.78 & 36.21 & 4.59 & 9.58 & 0.89 \\
& & & & & & & & & \\
31 & 12.5 & 1 & 34 & 27.91 & 1.82 & 78.89 & 8.62 & 9.70 & 1.21 \\
31 & 12.5 & 2 & 33 & 29.21 & 3.12 & 79.33 & 6.34 & 10.35 & 1.15 \\
31 & 7.5 & 3 & 35 & 29.74 & 2.16 & 66.53 & 8.73 & 9.65 & 1.35 \\
31 & 7.5 & 4 & 34 & 29.68 & 2.75 & 70.96 & 9.91 & 9.67 & 0.92 \\
\hline
\end{tabular}

the Day 31 sample in the first $5 \mathrm{~d}$ after Day 10, while this tendency seemed to be reversed in the low- ration bags. Except for the Day 20 sample, RGR was initially high ( $>8 \%$ ), but stabilised to a constant level of 6.5 to $7.5 \%$. Between Days 26 and 30, otolith growth was retarded in all bags. However, the decline in otolith growth was most pronounced in the low-ration bags, leading to a smaller radius than in the high-ration bags at Day 31. The last increments before experiment termination showed elevated growth in all bags.

Linear regressions were fitted to plots of otolith radius versus standard length. This relationship showed a good correlation within each bag, but for the entire larval period the residuals suggest that the use of polynoms may be more appropriate than the linear model (Fig. 5A). However, for the individual samples, correlations were not always significant (Table 2). No correlation between standard length and otolith radius was found for the Day 3 sample or the high ration groups of the Day 10 sample. A weak significant relationship was found for the low ration groups of the Day 10 sample. For the Day 20 and 31 samples, the correlations between radius and standard length or myotome height were highly significant. However, in the Day 31 sample, the 

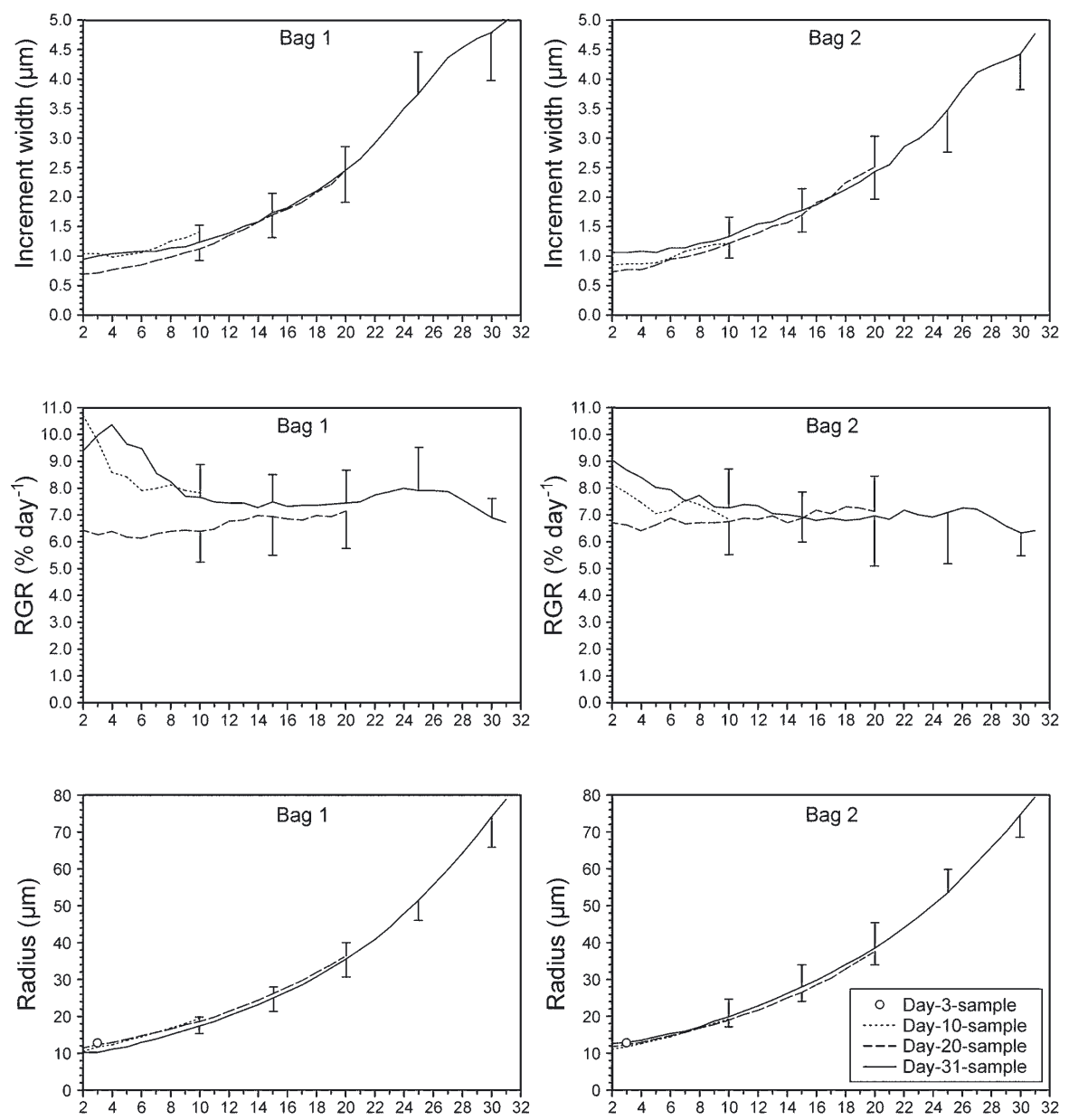

Fig. 3. Gadus morhua. Otolith characteristics of cod larvae form the high-ration enclosures (Bags 1 and 2). Increment width, relative otolith growth rate (RGR), and otolith radius are shown for samples at Days 10, 20, and 31 post-hatch. Radius of 3 d old yolksac larvae is also indicated. Standard deviations are shown for every 5 th day of the Day 20 and 31 samples

Increment number

radius of the low-ration larvae was bigger at similar standard lengths compared to the high-ration larvae (Fig. 5B) (ANCOVA, df $=131, \mathrm{p}=1.0 \times 10^{-13}$ ). Relationships between otolith radius and other linear somatic growth indices (myotome height, square root of the product between myotome and standard length, and cubic root of dry weight) matched the results of otolith radius versus standard length.

Considering the last otolith increment before sampling, correlations between otolith growth and larval size were low, and with one exception, not significant for larval standard length against RGR (Table 2). Similarly, larval standard length correlated significantly with increment width for the Day 20 and 31 samples, but not for the Day 10 sample.

\section{Growth- and size-dependent survival}

To evaluate growth- or size-specific effects within the rearing system, increment widths, RGR and radius at a similar age among the Day 10, 20, and 31 samples were compared within each of the bags. In most cases, when significant differences occurred in comparisons of samples for Increment 10, the surviving larvae were those individuals with low increment width, RGR and small radius (Fig. 6). However, several of the bags did not show significant differences. When comparing Increment 20 for each bag in a similar manner, almost no significant differences of increment width, RGR or radius were observed for the larvae surviving to Day 31.

A tendency to segregation of the 2 feeding regimes was observed for width and RGR of Increment 10 among larvae surviving to Day 31 (Fig. 6A,B), indicating higher growth rate in the high-ration group by Day 10 than in the low-ration group among the surviving larvae. A similar tendency to segregation also occurred in width of Increment 20 among larvae of the Day 31 sample, but not in RGR.

In general, early otolith growth in all bags (RGR before Day 9) appeared to be higher among the larvae surviving the period of prey switch between Days 20 and 31 (Figs. 3, 4, \& 7). In the high-ration bags, most of 

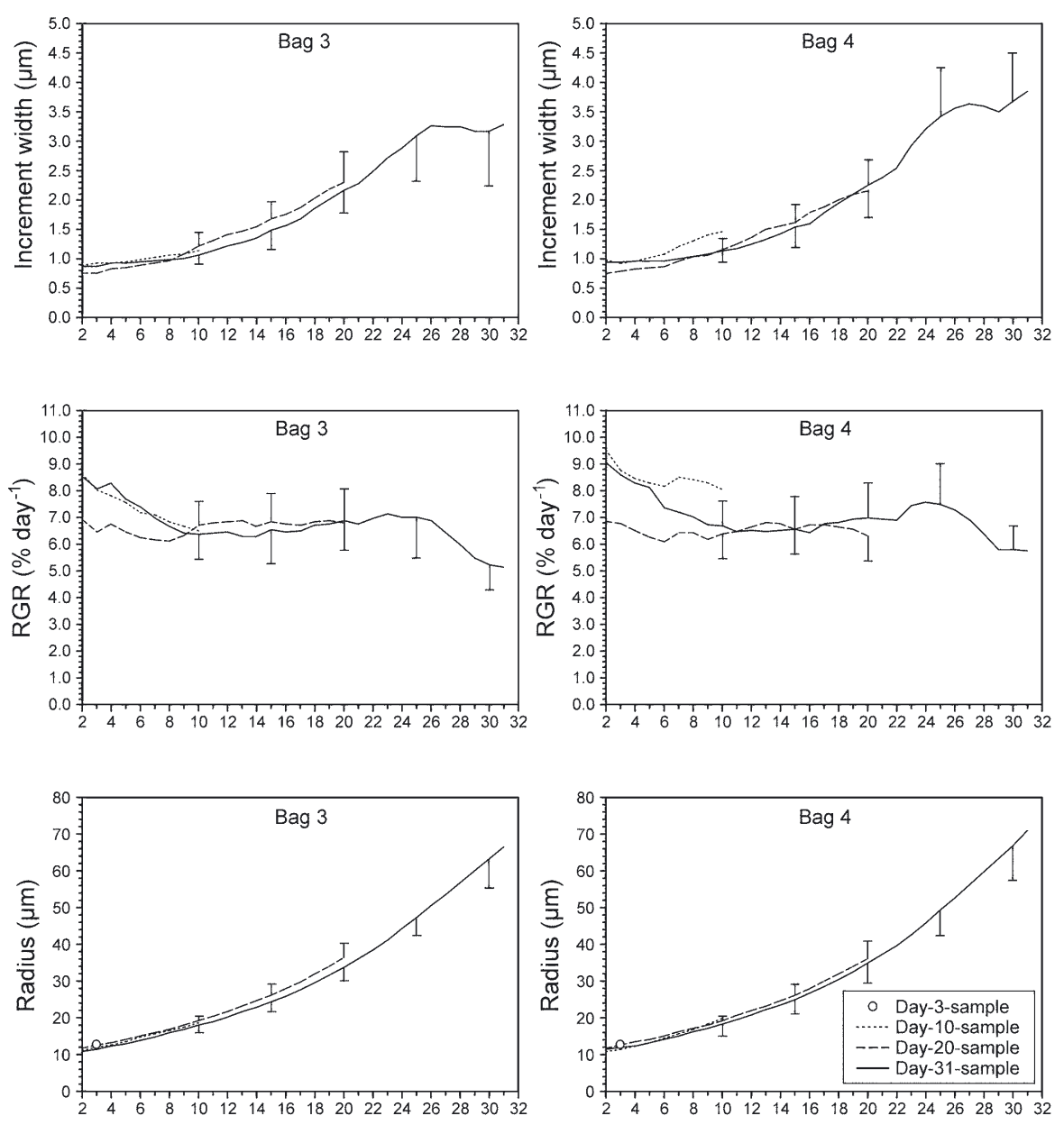

Fig. 4. Gadus morhua. Otolith characteristics of cod larvae form the lowration enclosures (Bags 3 and 4). Increment width, relative otolith growth rate (RGR), and otolith radius are shown for samples at Day 10, 20, and 31 post-hatch. Radius of $3 \mathrm{~d}$ old yolk-sac larvae is also indicated. Standard deviations are shown for every 5th day of the Day 20 and 31 samples the increments in the first $8 \mathrm{~d}$ post-hatch in larvae surviving from Day 20 to 31 were significantly larger than in the larvae from the Day 20 sample (Fig. 7). Larvae surviving the same period in the low-ration bags only showed this in the first $5 \mathrm{~d}$ post-hatch. Furthermore, the survivors between Days 20 and 31 in the low-ration larvae tended to have lower increment widths and RGRs between Days 11 and 15 than the larvae collected on Day 20 (Figs. 3, 4 \& 7). This difference was only significant for increment width in Bag 3. In contrast, the larvae surviving between Days 20 and 31 in the high-ration bags tended to have higher increment widths and RGRs between Days 10 and 15 than the larvae collected by Day 20 (Figs. 3, 4 \& 7). Again, this difference was only significant for 1 bag (RGR of Bag 1). Except for Bag 2, the larvae surviving the period between Days 20 and 31 were characterised by having a significantly smaller radius for all the increments before Day 20 (Fig. 7).

In all bags, a significant correlation was found between ranks of otolith radius in the Day 31 sample and ranks of radius in all previous increments (Fig. 8).
In contrast, ranks of increment width and RGR were only significant for the 4 to 8 previous increments. Ranks of increment width tended to be more positively correlated than ranks of RGR. A very similar picture appeared for the Day 20 sample.

\section{DISCUSSION}

\section{Feeding conditions and growth}

The very high specific somatic growth rates for some of the larval period (Fig. 1) are in accordance with previously reported growth in cod (van der Meeren \& Næss 1993, van der Meeren et al. 1994, Otterlei et al. 1999). The lack of differentiation in somatic growth between the 2 food regimes in the first 2 to $3 \mathrm{wk}$ may be explained by surplus food density for larval feeding, despite the attempts to regulate prey availability by the bioenergetic consumption model. This can partly be caused by the model itself, as it seemed to overestimate the energetic needs of young cod larvae. 

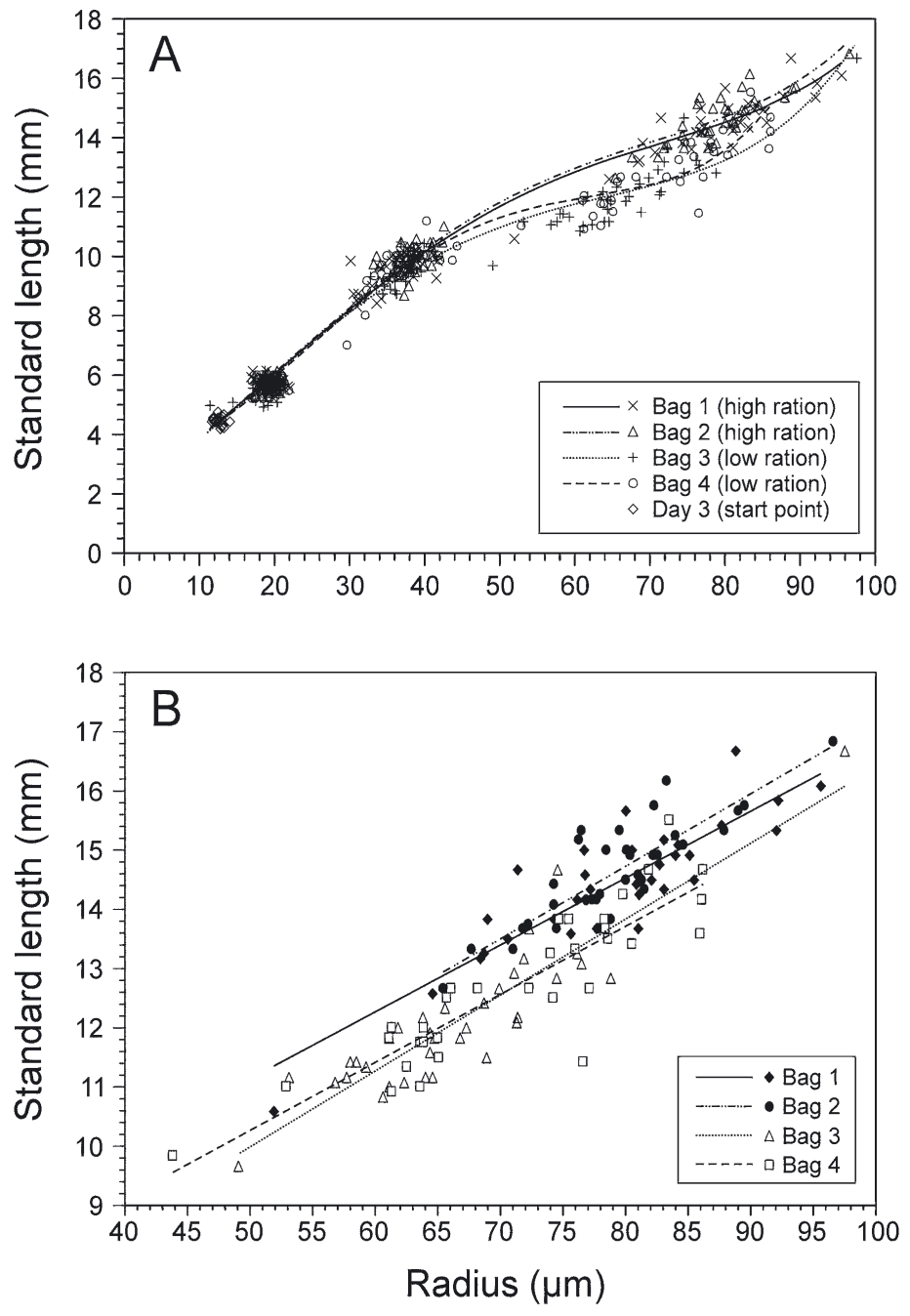

Table 2. Gadus morhua. Correlation statistics of the relationships $(y=a x+b)$ between larval size $(y=$ standard length in $\mathrm{mm})$ and otolith growth or size indices $(x=$ RAD: radius in $\mu \mathrm{m}, \mathrm{RGR}$ : relative otolith growth rate in \%, or INCR: increment width in $\mu \mathrm{m})$. Significant correlation coefficients (r) and p-values (p) are indicated in bold. SGR: specific growth rate

\begin{tabular}{|c|c|c|c|c|c|c|c|c|c|}
\hline \multirow{2}{*}{$\begin{array}{l}\text { Age } \\
\text { (d) }\end{array}$} & \multirow{2}{*}{$\begin{array}{c}\text { Food regime } \\
\text { (\% SGR) }\end{array}$} & \multirow{2}{*}{$\begin{array}{l}\text { Bag } \\
\text { no. }\end{array}$} & \multirow{2}{*}{$\begin{array}{l}\text { No. of } \\
\text { larvae }\end{array}$} & \multicolumn{2}{|c|}{ RAD } & \multicolumn{2}{|c|}{ RGR } & \multicolumn{2}{|c|}{ INCR } \\
\hline & & & & $\mathrm{r}$ & $\mathrm{p}$ & $\mathrm{r}$ & $\mathrm{p}$ & $\mathrm{r}$ & $\mathrm{p}$ \\
\hline 3 & - & $1-4$ & 19 & 0.096 & 0.6945 & & & & \\
\hline 10 & 12.5 & 1 & 29 & 0.287 & 0.1318 & 0.176 & 0.3625 & 0.078 & 0.6872 \\
\hline 10 & 12.5 & 2 & 33 & 0.215 & 0.2291 & 0.145 & 0.4210 & 0.176 & 0.3262 \\
\hline 10 & 7.5 & 3 & 36 & 0.400 & 0.0156 & 0.036 & 0.8734 & 0.187 & 0.4051 \\
\hline 10 & 7.5 & 4 & 38 & 0.397 & 0.0137 & 0.032 & 0.8756 & 0.130 & 0.5193 \\
\hline 20 & 12.5 & 1 & 31 & 0.646 & $9 \times 10^{-5}$ & 0.319 & 0.0807 & 0.511 & 0.0033 \\
\hline 20 & 12.5 & 2 & 34 & 0.816 & $4 \times 10^{-9}$ & 0.310 & 0.0749 & 0.578 & 0.0003 \\
\hline 20 & 7.5 & 3 & 28 & 0.913 & $1 \times 10^{-11}$ & 0.274 & 0.1582 & 0.410 & 0.0301 \\
\hline 20 & 7.5 & 4 & 34 & 0.883 & $5 \times 10^{-12}$ & 0.296 & 0.0892 & 0.672 & $1 \times 10^{-5}$ \\
\hline 31 & 12.5 & 1 & 34 & 0.883 & $5 \times 10^{-12}$ & 0.299 & 0.0858 & 0.710 & $3 \times 10^{-6}$ \\
\hline 31 & 12.5 & 2 & 33 & 0.857 & $2 \times 10^{-10}$ & 0.067 & 0.7333 & 0.537 & 0.0013 \\
\hline 31 & 7.5 & 3 & 35 & 0.905 & $9 \times 10^{-14}$ & 0.703 & $2 \times 10^{-6}$ & 0.868 & $2 \times 10^{-11}$ \\
\hline 31 & 7.5 & 4 & 34 & 0.884 & $4 \times 10^{-12}$ & 0.142 & 0.4238 & 0.712 & $2 \times 10^{-6}$ \\
\hline
\end{tabular}

Fig. 5. Gadus morhua. Relations between otolith size (mean radius of the lapilli) and standard length of Bags 1 to 4 . Overall polynomal relations (A) for Bag 1: $y=5 \times$ $10^{-7} X^{4}-0.0001 x^{3}+0.0048 x^{2}+0.129 x+2.166\left(\mathrm{R}^{2}=\right.$ 0.9853), Bag 2: $y=6 \times 10^{-7} x^{4}-0.0001 x^{3}+0.0054 x^{2}$ $+0.120 x-2.213\left(R^{2}=0.9897\right)$, Bag 3: $y=7 \times 10^{-7} x^{4}$ $-0.0001 x^{3}+0.0047 x^{2}+0.148 x+1.931\left(R^{2}=0.9779\right)$, Bag $4: y=2 \times 10^{-6} x^{4}-0.0003 x^{3}+0.0143 x^{2}-0.0711 x+3.484$ $\left(\mathrm{R}^{2}=0.9769\right)$. Relations of the Day 31 sample $(\mathrm{B})$ : see Table 2 for correlation coefficients and significance of the correlations

However, relative to the 2 feeding regimes, the model succeeded in creating differentiation in somatic growth rates in the last $2 \mathrm{wk}$ of the experiment.

Additional changes in the 2 feeding regimes occurred at the beginning of the 4 th wk post-hatch. Food supply was temporarily reduced, and prey composition was changed to larger prey types (Stage CIV-CVI copepods). This resulted in a reduction of somatic growth rate in all bag enclosures, which was also traced in the otoliths within a few days. Similarly, the otoliths responded quickly with increased growth when smaller and probably more suitable prey (nauplii and copepodites) became more abundant on Day 29. Thus, in accordance with Suthers et al. (1999), a short-term change in feeding conditions seems to be easily tracked in otoliths of cod larvae. A substantial part of the variation in deposition of daily rings may be explained by short-term physical variables, which may affect daily food availability, e.g. light or turbulence (Gallego et al. 1996). Cod larvae may then be ideal candidates to assess links among the physical environment, food conditions and larval performance.

\section{Otolith characteristics}

As also observed by Geffen (1995) and Otterlei et al. (2002), a significant correlation between otolith size and larval size occurred only for older larvae. Clemmesen \& Doan (1996) attributed the lack of such a relationship in early-stage cod larvae to a lack of influence by exogen food while yolk is still present. Meekan (1997) suggested the high relative size 

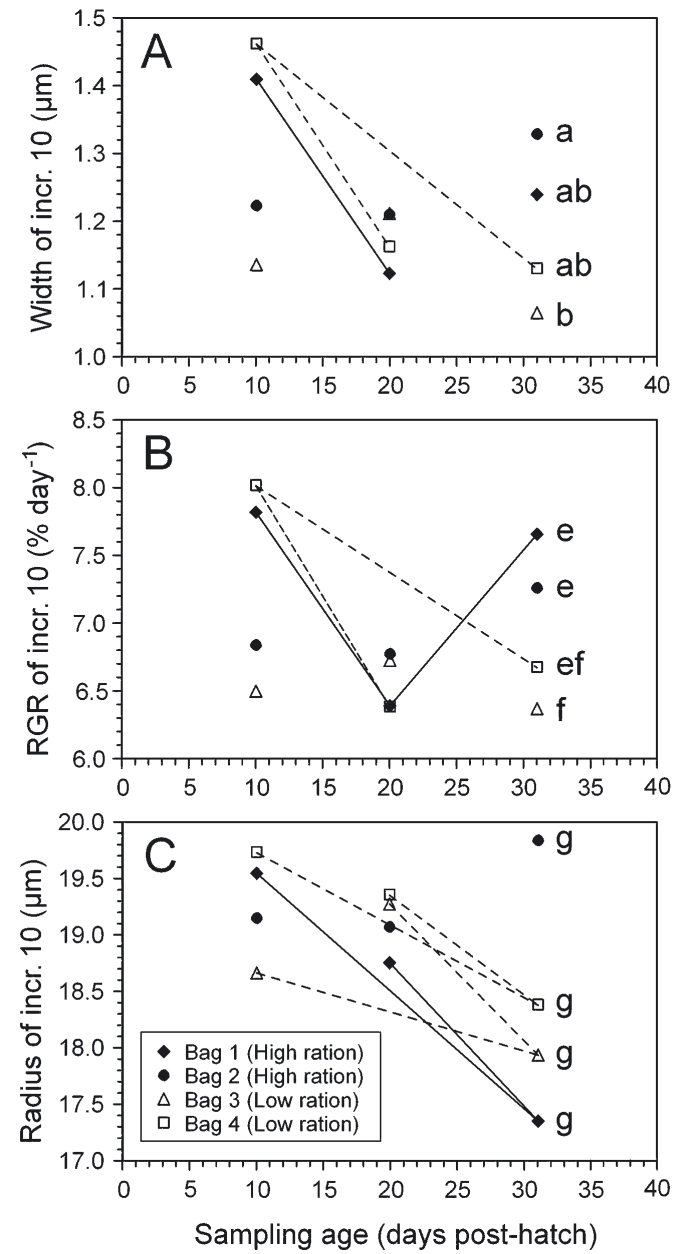

Fig. 6. Gadus morhua. Comparisons of width (A), relative growth rate $\left(\mathrm{RGR}_{i} \mathrm{~B}\right)$, and radius $(\mathrm{C})$ of Increment (incr.) 10 among the samples of Day 10, 20, and 31. Lines denote significant differences (2-tailed Kolmogorov-Smirnov 2-sample test) within each bag enclosure, solid line is high-ration bags and broken line is low-ration bags. Different lowercase letters are used to visualise significant differences between bag enclosures of the Day 31 sample

variation in early larval stages to count for a lack of relationship between larval body size and otolith size. However, the overall relationship between otolith radius and standard length was highly significant, but not linear. Non-linearity resulting from time-varying growth rates may have a profound influence on the results when body size is back-calculated from otolith size (Campana 1990). In contrast, other studies on larval cod otoliths have shown a linear relationship (lapillus radii of 40 to $300 \mu \mathrm{m}$ : Meekan \& Fortier 1996) or an exponential relationship (lapillus radii of 10 to $100 \mu \mathrm{m}$ : Geffen 1995).

Further, final otolith size of the low-ration larvae was relatively larger than that of the high-ration larvae at a similar length, and this developed late in the
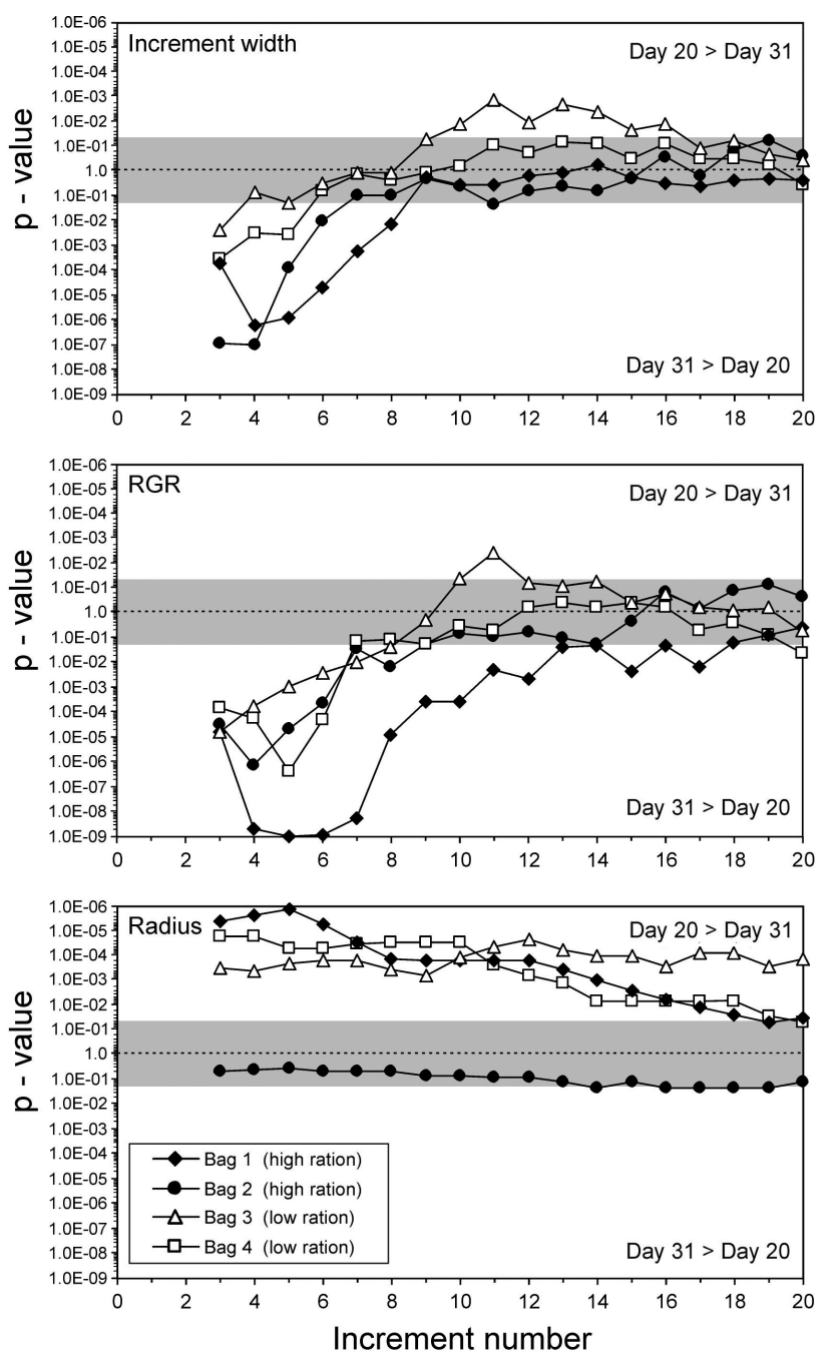

Fig. 7. Gadus morhua. Significance level (1-tailed p-values from the Kolmogorov-Smirnov 2-sample test) of differences in increment width. Relative growth rate (RGR) and radius at a given age (increment number $\leq 20$ ) of the samples on Days 20 and 31 in Bags 1 to 4 . Grey area denotes lack of significance ( $p$-values $>0.05$ ), and white areas denote that the Day 20 sample is either larger (upper part of panels) or lower (lower part of panels) than the Day 31 sample

experiment during the period of change in prey composition. Obviously, otolith growth may be somewhat decoupled from somatic growth when variations in SGR occur due to alterations in feeding conditions. Similar observations have been made in other fish larvae (Brothers 1981, Secor \& Dean 1992, Hare \& Cowen 1995), but this was not found in herring larvae exposed to fluctuating food availability (Folkvord et al. 2000), or in striped bass larvae (Dickey et al. 1997). Heath (1992) reviewed the decoupling of otolith and somatic growth, a phenomenon that has been observed in a number of marine larval fish species. Both temperature and metabolic rate have been sug- 


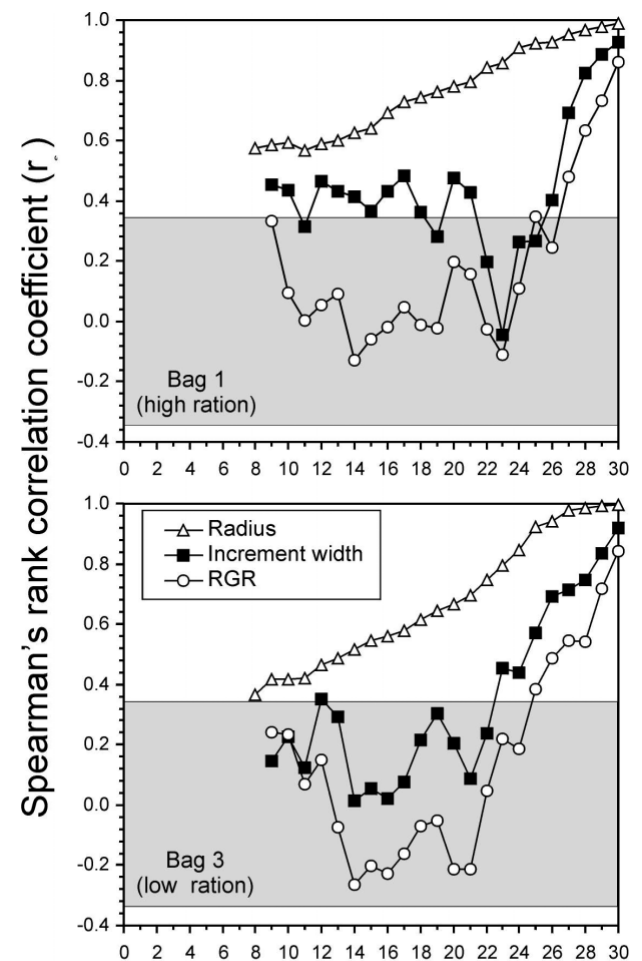

Increment number
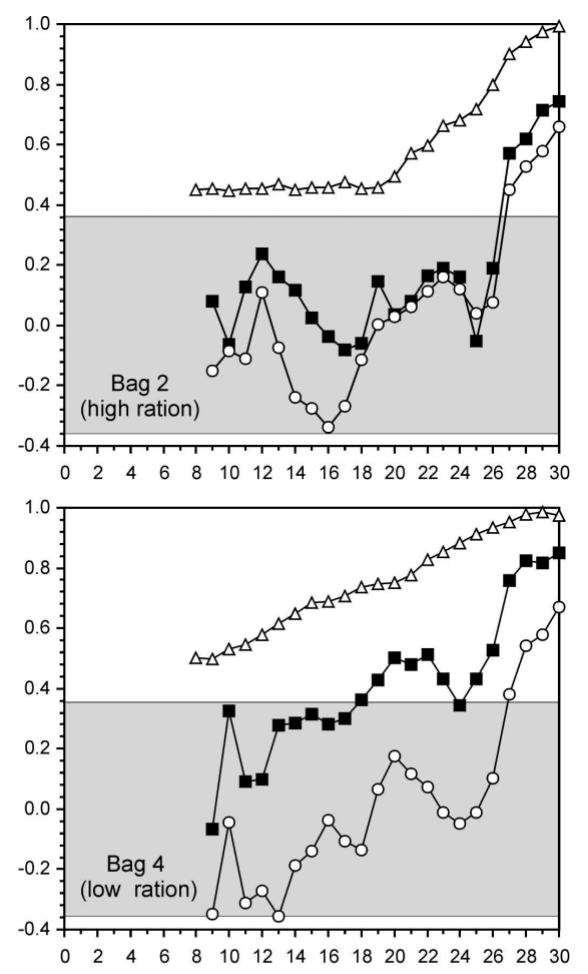

Fig. 8. Gadus morhua. Correlation between ranked otolith characteristics of the last increment and previous increments of the Day 31 sample in Bags 1 to 4 . The grey area in the figures encloses values of the Spearman rank correlation coefficient $\left(\mathrm{r}_{\mathrm{s}}\right)$ that are not significant. RGR: relative growth rate gested to correlate with otolith growth (Brothers 1981, Mosegaard et al. 1988, Wright 1991). Otterlei at al. (2002) showed that increasing temperature resulted in proportionally larger otolith size for cod of a given length, compared to larvae reared at lower temperatures. They also observed a tendency of proportionally smaller otoliths in faster growing individuals within a similar temperature range. Secor \& Dean (1989) proposed 2 components of the daily otolith increment deposition: 1 independent of and 1 in proportion to daily somatic growth. The independent component may be derived from metabolism and, thus, be dependent on temperature, while the somatic component may be correlated with food availability. Food availability is a proxy for food ingestion and has a great influence on both somatic growth and metabolic rates (Warren \& Davis 1967). Thus, consistent changes in temperature or food availability may, differentially affect the 2 components of otolith growth, and hence alter the expected linear relationships between otolith and larval size. In the present study, an initial linear relationship changed to non-linearity when food availability reduced somatic growth in the 2 larval feeding groups, and temperature increased by $3^{\circ} \mathrm{C}$ throughout the experiment. Since the lowration larvae were most affected, the magnitude of this effect is apparently dependent on the degree of food deprivation. However, in the sea, predation may complicate the picture by removing the slow-growing individuals. The surviving and more rapid-growing larvae will make the population size-to-age relationship more uniform and counteract a non-linear relationship between otolith and larval size, as imposed on larval development by changes in environmental factors.

Based on the ranks of otolith size, cod larvae maintained their position in the population hierarchy throughout the larval period. However, the observed lack of relationship between larval and otolith size at a certain age during early developmental stages indicates that a cod larva, based on its size, may keep its hierarchic position within the population from the 2 nd or 3rd wk after hatching. Obviously, within the surviving part of the initial population, larvae with large otoliths in the early stages seem to become large larvae later. Do such larvae with initial large otoliths have better capabilities of somatic growth, or are they the large individuals among the larvae with initial large otoliths? This cannot be answered from the present study. In this context, both otolith size at similar length and overall somatic growth rate was higher for Norwegian coastal cod compared to Arcto-Norwegian cod when they were co-reared under the exact same conditions (van der Meeren et al. 1994, van der Meeren \& Jørstad 2001, Otterlei et at. 2002). Looking to otolith growth as a proxy for somatic growth, recent otolith 
growth is only significantly correlated with previous growth history over the last 4 to 8 increments, which is in accordance with observations of other marine fish larvae (Gallego et al. 1996, 1999). Thus, during development considerable variation in the otolith growth trajectory may occur independently among individuals, causing alterations in the population growth-rate hierarchy. Gallego et al. (1996) suggested that variation in growth specific to each larva is likely to be the outcome of complex interaction between factors such as genetic variability among individuals in the population, foraging experience, and small-scale heterogeneity in the larval environment. Otolith radius represents the accumulated effect of daily growth increments, and the daily shifts in growth rate among individuals is apparently not large enough to significantly change the population rank of otolith size.

\section{Growth- and size-dependent mortality}

Selective mortality between Day 20 and 31 posthatch was apparently strongly dependent on otolith growth rate in the 1st wk after stocking (Fig. 7). However, this can be explained entirely by the lack of detection of increments in the Day 31 sample. Similarly, lack of rings occurred in the Day 10 sample, resulting in apparently high initial growth rates (Figs. 3 \& 4). This was not shown for the Day 20 sample, where the number of increments corresponded with age. RGR seemed to be most sensitive to erroneous increment counts, and indicates that failure of ring detection occurred among the early increments before Day 10. Most likely, this is due to resolution limitations in the use of light microscopy (Campana et al. 1987). Conclusions on early growth- or size-dependent mortality should be made with care, and was therefore restricted to comparisons of increments from Day 10 and onwards in the present data.

The distinction between the terms 'size-selective' as selection for certain larval sizes, and 'growth-dependent' as selection for larvae with certain growth rates, is also important (Hovenkamp 1992). When using otoliths as a measure for larval growth (increment width: absolute growth, RGR: relative growth, and radius: accumulated growth), significant correlations between larval size and the otolith growth index are required to interpret growth-dependent selection as size-dependent selection. Sampling the same larval population several times enables evaluation of size- or growth-dependent selection happening at different times of development.

In the present experiment, it seems difficult to conclude that mortality was clearly growth-dependent. Considering the last increment of the Day 10 sample
(Increment 10) and its fate in the further rearing of the larvae, no consistent pattern in growth-selective mortality was observed. At least 2 of the 4 bags $(1$ from each feeding regime) did not show significant differences in width and RGR of this increment in the later samples. However, whenever significant differences occurred, mostly slow-growing individuals (low increment width and RGR) had a greater survival probability (Fig. 6A,B). This trend for slow-growing larvae to survive was most pronounced between Days 10 and 20, when the larvae were in the period of surplus feeding conditions. The apparent trend for growth-dependent survival may not be regarded as a selection for small larvae to survive, since no significant relationships between larval size and otolith growth indices (increment width and RGR) were established at this early stage of development (Table 2).

As radius represents the cumulative effect of daily otolith growth, the observed trend in growth-dependent mortality was more strongly observed as a significant selection for small otolith radius from Day 10 to 31 (Fig. 6C). This selection for an initially small otolith radius happened particularly between Days 20 and 31 , when the food type offered was switched to larger prey. Since a significant correlation between larval size and otolith radius at Day 10 was also weak or lacking, evidence for larval size-dependent mortality (or survival) at this early stage cannot be extracted. However, the selection for small otolith size is also observed for increments towards Day 20 (Fig. 7). By Day 20, the relationships between SL and otolith sizes are significant, and a selection for small members of the population close to this age may be suggested. It should be noted that Campana (1989) reported the cod lapillus to have allometric growth, shifting the axis of maximum diameter orthogonally. This may lead to errors when comparing the radius of a selected increment number between samples of different ages. This effect was checked on otoliths of the Day 31 sample, and an overestimation of 0.9 and $2.4 \%$ was found for radius at Increments 10 and 20 of the Day 31 sample, respectively. Thus, the observed selections for smaller otoliths may be slightly stronger than presented. Grimes \& Isely (1996) reported a trend in sizespecific survival of smaller individuals in laboratoryreared gulf menhaden Brevoortia patronus under good feeding conditions. On the other hand, lack of strong growth-dependent survival in the present data is in disagreement to other observations of marine fish larvae reared in predator-free mesocosms (Rosenberg \& Haugen 1982, Folkvord et al. 1997). A major difference is that these experiments showed extremely adverse feeding conditions compared to the present study (for evaluation of feeding conditions in the experiment of Rosenberg \& Haugen 1982, see Dani- 
elssen et al. 1990). This probably resulted in much lower survival, enabling possible growth-specific effects to appear more readily than in the present experiment.

Another interesting feature of the growth-selective processes is that the actual changes in food regime (surplus feeding conditions in the first $2 \mathrm{wk}$, and 2 distinct feeding regimes later) had a propensity to cause early otolith growth (width and RGR of Increment 10) of the surviving larvae to segregate in the same manner as the feeding regimes (Fig. 6A,B). Previous growth history may, therefore, to some extent influence selective forces relative to the actual feeding regime which larvae are exposed to. Probably the degree of match between larval size and prey size may play a role in such selections, where larval size is the cumulative result of previous growth history.

According to Ricker (1969), it takes a rather large selective mortality to produce a rather small shift in trait size. In the sea, mortality is extremely high compared with the results from the mesocosm experiments, and even moderate selective forces may readily appear. Detection of selective processes in the mesocosms is more difficult because they have to be very strong to appear when survival is as high as $50 \%$. The present work showed only weak evidence of growthdependent mortality, which theoretically can also be explained by factors like biased sampling or technical difficulties in reading the correct size of the trait investigated (Ricker 1969). It may therefore be concluded that in a situation with adequate feeding conditions and exclusion of predators, growth and mortality rates seem not to be very well correlated among different parts of the larval population. This indicates that no strong inherent mechanisms in the larvae are responsible for growth-dependent mortality. Such selection may then be a result of exogen factors such as predation or dramatic limitations in food availability.

Acknowledgements. The study was supported by EU, project no. FAIR-CT95-0084. We wish to thank laboratory assistant I. Henriksen at Flødevigen Marine Research Station for her skilled work on preparing and reading the otoliths. We also thank T. Lønøy at the Institute of Fisheries and Marine Biology, University of Bergen, for his assistance in compiling and preparing the mesocosms and bag enclosure system.

\section{LITTERATURE CITED}

Bailey KM, Houde ED (1989) Predation on eggs and larvae of marine fishes and the recruitment problem. Adv Mar Biol 25:1-83

Blom G, Svåsand T, Jørstad KE, Otterå H, Paulsen OI, Holm JC (1994) Comparative survival and growth of two strains of Atlantic cod Gadus morhua through the early life stages in a marine pond. Can J Fish Aquat Sci 51:1012-1023

Brothers EB (1981) What can otolith microstructure tell us about daily and subdaily events in the early life history of fish? Rapp p-v Réun Cons Int Explor Mer 178:393-394

Butler J, Moksness E (1997) Manual for OTO 30 and OPS programs for reading daily increments. US Department of Commerce, La Jolla, CA. (NOAA Technical Memorandum NMFS-SWFSC-238) SH11. C47 no. 238, p 1-57

Campana SE (1989) Otholith microstructure of three larval gadids in the Gulf of Maine, with references on early life history. Can J Zool 67:1401-1410

Campana SE (1990) How reliable are growth back-calculations based on otoliths? Can J Fish Aquat Sci 47:2219-2227

Campana SE, Gagne JA, Munro J (1987) Otolith microstructure of larval herring (Clupea harengus): image or reality? Can J Fish Aquat Sci 44:1922-1929

Clemmesen C, Doan T (1996) Does otolith structure reflect the nutritional condition of fish larvae? Comparison of otolith structure and biochemical index (RNA/DNA ratio) determined on cod larvae. Mar Ecol Prog Ser 138:33-39

Cowan JH Jr, Houde ED (1990) Growth and survival of bay anchovy Anchoa mitchilli larvae in mesocosm enclosures. Mar Ecol Prog Ser 68:47-57

Cowan JH Jr, Houde ED (1992) Size-dependent predation on marine fish larvae by Ctenophores, Scyphomedusae, and planktivorous fish. Fish Oceanogr 1:113-126

Danielssen DS, Haugen AS, Øiestad V (1990) Survival and growth of turbot (Scophthalmus maximus L.) in a landsituated mesocosm. Flødevigen rapportser 2:11-45

Dickey CL, Isely JJ, Tomasso JR (1997) Slow growth did not decouple the otolith size fish size relationship in striped bass. Trans Am Fish Soc 126(6):1027-1029

Folkvord A, Rukan K, Johannessen A, Moksness E (1997) Early life history of herring larvae in contrasting feeding environments determined by otolith microstructure analysis. J Fish Biol 57 (Suppl A):250-263

Folkvord A, Blom G, Johannesen A, Moksness E (2000) Growth dependent age estimation in herring (Clupea harengus L.) larvae. Fish Res 46:91-103

Gallego A, Heath M (1997) The effect of growth-dependent mortality, external environment and internal dynamics on larval fish otolith growth: an individual-based modelling approach. J Fish Biol 57(Suppl A):121-134

Gallego A, Heath MR, McKenzie E, Cargill LH (1996) Environmentally induced short-term variability in the growth rates of larval herring. Mar Ecol Prog Ser 137:11-23

Gallego A, Heath M, Basford D, Mackenzie B (1999) Variability in growth rates of larval haddock in the northern North Sea. Fish Oceanogr 8:77-92

Geffen AJ (1995) Growth and otolith microstructure of cod (Gadus morhua L.) larvae. J Plankton Res 17:783-800

Grimes CB, Isely JJ (1996) Influence of size-selective mortality on growth of gulf menhaden and king mackerel larvae. Trans Am Fish Soc 125:741-752

Grønkjær P, Schytte M (1999) Non-random mortality of Baltic cod larvae inferred from otolith hatch-check sizes. Mar Ecol Prog Ser 181:53-59

Hare JA, Cowen RK (1995) Effect of age, growth rate, and ontogeny on the otolith size-fish size relationship in bluefish, Pomatomus saltatrix, and the implication for back-calculation of size in fish early life history stages. Can J Fish Aquat Sci 52:1909-1922

Heath MR (1992) Field investigations of the early life stages of marine fish. Adv Mar Biol 28:1-174

Houde ED (1989) Comparative growth, mortality, and energetics of marine fish larvae: temperature and implied latitudinal effects. Fish Bull US 87:471-495

Houde ED (1997) Patterns and trends in larval-stage growth and mortality of teleost fish. J Fish Biol 57(Suppl A):52-83

Houde ED, Schekter RC (1981) Growth rates, rations and 
cohort consumption of marine fish larvae in relation to prey concentrations. Rapp p-v Reun Cons Int Explor Mer 178:441-453

Hovenkamp F (1992) Growth-dependent mortality of larval plaice Pleuronectes platessa in the North Sea. Mar Ecol Prog Ser 82:95-101

Kiørboe T (1989) Growth in fish larvae: are they particularly efficient? Rapp p-v Reun Cons Int Explor Mer 191:383-389

Kristiansen TS, Jørstad KE, Otterå H, Paulsen OI, Svåsand T (1997) Estimates of larval survival of cod releases of genetically marked yolk-sac larvae. J Fish Biol 57(Suppl A): $264-283$

Margulies D (1989) Effects of food concentration and temperature on development, growth and survival of white perch, Morone americana, eggs and larvae. Fish Bull US 87:63-72

McGurk MD (1986) Natural mortality of marine pelagic fish eggs and larvae: role of spatial patchiness. Mar Ecol Prog Ser 34:227-242

Meekan M (1997) Relationships between otolith and somatic growth of cod larvae (Gadus morhua). J Plankton Res 19: 167-169

Meekan M, Fortier L (1996) Selection for fast growth during the larval life of Atlantic cod Gadus morhua on the Scotian Shelf. Mar Ecol Prog Ser 137:25-37

Mosegaard H, Svedäng H, Taberman K (1988) Uncoupling of somatic and otolith growth rates in Arctic charr (Salvelinus alpinus) as an effect of differences in temperature response. Can J Fish Aquat Sci 45:1514-1524

Naas KE, van der Meeren T, Aksnes DL (1991) Plankton succession and responses to manipulations in a marine basin for larval rearing. Mar Ecol Prog Ser 74:161-173

Øiestad V (1983) Growth and survival of herring larvae and fry (Clupea harengus L.) exposed to different feeding regimes in experimental ecosystems: outdoor basin and plastic bags. PhD thesis, University of Bergen

Øiestad V (1985) Predation on fish larvae as a regulatory force, illustrated in mesocosm studies with large groups of larve. Northwest Atlantic Fisheries Organization Scientific Council Studies 8:25-32

Otterlei E, Nyhammer G, Folkvord A, Stefansson SO (1999) Temperature- and size-dependent growth of larval and early juvenile Atlantic cod (Gadus morhua): a comparative study of Norwegian coastal cod and northeast Arctic cod. Can J Fish Aquat Sci 56:2099-2111

Otterlei E, Folkvord A, Nyhammer G (2002) Temperature dependent otolith growth of larval and early juvenile Atlantic cod (Gadus morhua). ICES J Mar Sci 59: 401-410

Paulsen H, Andersen NG (1989) Extensive rearing of turbot larvae (Scophthalmus maximus L.). In: De Pauw N, Jaspers E, Ackefors H, Wilkins N (eds) Aquaculture-a biotechnology in progress. European Aquaculture Society, Bredene, Belgium, p 241-248

Pepin P (1989) Effect of temperature and size on development, mortality and survival rates of the pelagic early life history stages of marine fish. Can J Fish Aquat Sci 48: 503-518

Peterson I, Wroblewski JS (1984) Mortality rate of fishes in the pelagic ecosystem. Can J Fish Aquat Sci 41:1117-1120

Post JR, Prankevicius AB (1987) Size-selective mortality in young-of-the-year yellow perch (Perca flavescens): evidence from otolith microstructure. Can J Fish Aquat Sci $44: 1840-1847$

Editorial responsibility: Thomas Kiorboe, Charlottenlund, Denmark
Ricker WE (1958) Handbook of computations for biological statistics of fish populations. Bull Fish Res Board Can 119: $1-300$

Ricker WE (1969) Effects of size-seletive mortality and sampling bias on estimates of growth, mortality productiuon and yield. J Fish Res Board Can 26:479-541

Rosenberg AA, Haugen AS (1982) Individual growth and size-selective mortality of larval turbot (Scophthalmus maximus) reared in enclosures. Mar Biol 72:73-77

Secor DH, Dean JM (1989) Somatic growth effects on otolith-fish size relationship in young pond-reared striped bass, Morone saxatilis. Can J Fish Aquat Sci 46: 113-121

Secor DH, Dean JM (1992) Comparison of othotith-based back-calculation methods to determine growth histories of larval striped bass, Monroe saxatilis. Can J Fish Aquat Sci 49:1439-1454

Sokal RR, Rohlf FJ (1995) Biometry, 3rd edn. WH Freeman, New York

Sundby S, Bjørke H, Soldal AV, Olsen S (1989) Mortality rates during the early life stages and year-class strength of the North-east arctic cod (Gadus morhua L.). Rapp p-v Réun Cons Int Explor Mer 191:351-358

Suthers I (1996) A guide to the extraction and interpretation of otoliths from larval and pelagic juvenile Arto-Norwegian cod (Gadus morhua). Fisk Havet 13:1-19

Suthers IM, van der Meeren T, Jørstad KE (1999) Growth histories derivied from otolith microstructure of three Norwegian cod stocks co-reared in mesocosms; effect of initial size and prey size changes. ICES J Mar Sci 56: 658-672

Tsukamoto K, Kuwada H, Hirokawa J, Oya M, Sekiya S, Fujimoto H, Imaizumi K (1989) Size-dependent mortality of red sea bream, Pargus major, juveniles released with fluorescent otolith-tags in News Bay, Japan. J Fish Biol 35 (Suppl A):59-69

van der Meeren T (1991) Selective feeding and prediction of food consumption in turbot larvae (Scophthalmus maximus L.) reared on the rotifer Brachionus plicatilis and natural zooplankton. Aquaculture 93:35-55

van der Meeren T, Jørstad KE (2001) Growth and survival of Arcto-Norwegian and Norwegian coastal cod larvae (Gadus morhua L.) reared together in mesocosms under different light regimes. Aquacult Res 32:549-563

van der Meeren T, Naas KE (1997) Development of rearing techniques using large enclosed ecosystems in the mass production of marine fish fry. Rev Fish Sci 5(4):367-390

van der Meeren T, Næss T (1993) How does cod (Gadus morhua L.) cope with variability in feeding conditions during early larval stages? Mar Biol 116:637-647

van der Meeren T, Jørstad K, Solemdal P, Kjesbu OS (1994). Growth and survival of cod larvae (Gadus morhua L.): comparative enclosure studies of northeast Arctic cod and coastal cod from western Norway. ICES Mar Sci Symp 198: 633-645

Ware DM (1975) Relation between egg size, growth natural mortality of larval fish. J Fish Res Board Can 32:2503-2512

Warren CE, Davis GE (1967) Laboratory studies on the feeding, bioenergetics, and growth of fish. In: Gerking SD (ed) The biological basis of freshwater fish production. John Wiley \& Sons, New York

Wright PJ (1991) The influence of metabolic rate on otolith increment width in Atlantic salmon parr, Salmo salar L. Can J Fish Aquat Sci 38:929-933

Submitted: May 5, 2002; Accepted: September 29, 2003 Proofs received from author(s): December 4, 2003 